\section{俩 Heighten Science \\ P U B L I C I T I O N S Corporation \\ ISSN \\ 2575-0135}

*Address for Correspondence: Cristian Antonio Rojas, Federal University of Latin American Integration, Foz do Iguaçu 85866-000, Brazil, Email: cristian.rojas@unila.edu.br

Submitted: 21 December 2018

Approved: 11 March 2019

Published: 12 March 2019

Copyright: @ 2019 Geisler SA, et al. This is an open access article distributed under the Creative Commons Attribution License, which permits unrestricted use, distribution, and reproduction in any medium, provided the original work is properly cited

Keywords: Abiotic stress; Low-temperature responses; Acclimation

Check for updates

\title{
Evaluation of cold response in Ilex paraguariensis
}

\author{
Sandonaid Andrei Geisler ${ }^{1}$, Carina Francisca Argüelles $^{2}$ and \\ Cristian Antonio Rojas ${ }^{1 *}$ \\ 'Federal University of Latin American Integration, Foz do Iguaçu 85866-000, Brazil \\ ${ }^{2}$ General Applied Genetics Research Group (GIGA), IBS - Nodo Posadas, UNaM - CONICET, \\ Posadas, Misiones, Argentina
}

\section{Abstract}

Ilex paraguariensis, also known as 'Yerba mate', occurs naturally in Argentina, Brazil and Paraguay and is also grown in these countries with different intensities. Leaves and branches of this plant are used in the preparation of a stimulant beverage that beside social importance has notorious health impact. However, the cultivated herbs present low productivity, due to deficiencies in cultivation and harvesting techniques, as well as due to the abiotic stresses that this species is subject to. The discovery and characterization of cold response mechanisms in plants such as Arabidopsis thaliana, began research in order to unravel the physiological and molecular mechanisms in response to cold in other plant species. In this work, we studied the physiological response observed in llex paraguariensis plants submitted to low temperatures $\left(0^{\circ} \mathrm{C}\right)$, with or without a pre-moderate acclimatization treatment period of $\left(8^{\circ} \mathrm{C}\right)$.

Our results suggest the existence of an acclimation response in llex paraguariensis, similar to that described in other species of the same temperature.

\section{Introduction}

Having its origin in South America, yerba mate (Ilex paraguariensis St Hill.) occurs naturally in many countries of South America. According to government data, Brazil, Argentina and Paraguay produce about $860,000,690,000$ and 85,000 tons, respectively [1]. Approximately $80 \%$ of the Brazilian production of yerba mate is destined for the domestic market. This species presents benefits for human health due to the presence of polyphenols, saponins, vitamins, flavonoids, amino acids, caffeine and Theobromine [2].

Its leaves and branches are used mainly in the production of beverages, such as chimarrão and teas, and for this reason the species plays a major socioeconomic importance for the southern region of Brazil, Argentina, Uruguay and Paraguay, being produced under cultivation or by extractivism [3]. Erva-mate has also evolved to be a source of caffeine in parallel with coffee and tea, as well as a therapeutic agent for its pharmacological properties linked LDL-cholesterol reduction, ability to act as antiinflammatory and contribute to the resistance of the break of the double strand of DNA induced by hydrogen peroxide [4]. However, according to Resende et al. [5], cultivated herbs present low productivity, due to deficiencies in cultivation and harvesting techniques, low genetic and physiological quality of the seeds used and abiotic stress. Cold, dry and high salinity conditions are common abiotic stresses that negatively affect plant growth and plant species production $[6,7]$.

For Taiz \& Zeiger [8], stress is defined as any external factor that exert a disadvantageous influence on the plant. In most cases, stress is evaluated in relation to plant survival, growth (biomass) or the primary processes of assimilation (absorption 
of $\mathrm{CO}_{2}$ and minerals) that are related to its complete development. In particular, stress due to low temperatures represents one of the main constraints to plant growth, development and distribution. Low temperature stress can be classified as chilling stress $\left(0-10^{\circ} \mathrm{C}\right)$ or freezing stress $\left(<0^{\circ} \mathrm{C}\right)$ [9]. Most tropical and subtropical plant species do not have the ability to adapt to cooling temperatures and therefore suffer damage from temperatures below $10^{\circ} \mathrm{C}$ which happen approximately for three months a year in the south and southeast region of Brazil [10]. When plants grow at relatively high temperatures $\left(25^{\circ} \mathrm{C}\right.$ to $\left.35^{\circ} \mathrm{C}\right)$ and are suddenly cooled, cooling damage occurs: growth slows down, discoloration or lesions appear on the leaves and the foliage appears as if it were soaked in water for a long period [8].

Thomashow [11], states that plants from temperate regions, such as spinach and Arabidopsis, generally exhibit a varying degree of cold tolerance and may increase their tolerance to freezing during exposure to low temperatures. On the other hand, plants of tropical and subtropical origin are sensitive to stress. The plants can perceive the low temperature through changes in the physical properties of their membranes, since the membrane fluidity is reduced during cold stress [12]. This mechanisms developed by plants to resist cold when exposed to non-freezing temperatures is known as acclimation, in which brief exposures to non-freezing temperatures (which occur early in winter) are used for metabolic preparation to avoid frosts.

The general hypothesis of our work is that Ilex paraguariensis could have mechanisms involved in the response to cold and that these mechanisms could help this species to withstand the low temperatures in certain situations. The objective of this work was to study the physiological response observed in yerba mate plants submitted to an acclimatization treatment (moderate cold) before exposure to the most severe cold.

\section{Materials and Methods}

All the plants used were three months old and were obtained from a commercial orchard where the germination was carried out on a substrate composed of pine bark and fertilizer Osmocote 14-14-14 grown in pots. All plants received the same conditions of irrigation, light and temperature. To participate in our trials the plants were selected by height and morphological appearance. The leaves were measured and counted to establish inclusion limits. Plants were chosen that had between 11 and $14 \mathrm{~cm}$ in length of the aerial part and between 10 and 13 total leaves. The leaf size limits were 5 to $7 \mathrm{~cm}$ long. The plants also did not contain spots or some other visible sign.

After selection, the plants were conditioned and maintained for 7 days in a forced ventilation growth chamber, at $25^{\circ} \mathrm{C}$ and photoperiod of $12: 12$, for all plants in all treatments, except those under stress. Hydration of the substrate was checked every 24 hours and redone when necessary. The selected plants (108 in total) were numbered, drawn and divided into 6 groups: 5 of them were subjected to a pretreatment consisting of exposure to $8^{\circ} \mathrm{C}$ for different periods of time. The sixth group of plants, represented by a general control, was in the same conditions of hydration and light, at $25^{\circ} \mathrm{C}$, throughout the study. The different treatments are detailed below:

The 5 groups were pretreated for $72,48,24$ and 12 and 0 hours at $8^{\circ} \mathrm{C}$. The last group with 0 hours of exposure at $8^{\circ} \mathrm{C}$ corresponds to the pre-treatment control (remaining at $25^{\circ} \mathrm{C}$ ). After pre-treatment at $8^{\circ} \mathrm{C}$ for different periods of time, the 5 groups of plants were conditioned in a ventilated growth chamber at $0^{\circ} \mathrm{C}$ for 48 hours. After 48 hours all plants (including general control) were visually assessed for signs of physiological changes.

\section{Results and Discussion}

Ilex paraguariensis, a plant species of subtropical origin, may have among limitations 
that affect culture, stress sensitivity due to low temperatures, as in other plant species [11]. To evaluate the physiological response visible to the stress of low temperatures and to a possible mechanism of acclimatization as protection in Ilex paraguariensis.

It has been described that several plant species have a mechanism called acclimatization, as a defense for periods of cold stress. This mechanism consists of taking advantage of short periods of moderate cold to activate the physiological and biochemical pathways that allow to support more intense cold later $[13,14]$. The results observed in the present work also suggest the existence in Ilex paraguariensis of a pre-programmed cold response by a period of acclimatization. In our experiment, plants that remained for 72 hours in a period of acclimatization at $8^{\circ} \mathrm{C}$ endured well the posterior cold of $0^{\circ} \mathrm{C}$, and only $10 \%$ of the plants in this group had black spots on their leaves. In the plants of the group of 48 hours of acclimatization, $25 \%$ had black spots on their leaves. In plants of the group of 24 hours of acclimatization, $50 \%$ of the plants had spots on their leaves. Similarly, plants of the 12 -hour group, also $50 \%$ of the plants had black spots on their leaves. On the other hand, $80 \%$ of the plants without acclimatization died. The acclimation process was the most beneficial after 72 hours, indicating that the process need time for metabolic changes and for the activation of gene expression. These results show that plants that were pretreated at $8^{\circ} \mathrm{C}$ showed higher protection against cold stress compared to plants without pre-treatment, and that protection was higher in plants that remained previously for a longer period of time at $8^{\circ} \mathrm{C}$, ?suggesting that a period of 72 hours or more of $8^{\circ} \mathrm{C}$ acclimatization would be required for plants to be molecularly adapted to a period of freezing.

Like all agricultural crops, the production of yerba mate is influenced by a large number of environmental factors, and the search for high yields at low costs implies a better understanding of the physiology and genetics of the crop. For Rocha et al. [15], few studies have been conducted to unravel the responses in yerba mate to biotic and abiotic stresses. However, there is much more research being conducted regarding tolerance mechanisms for stresses in species such as corn, rice, wheat, Arabidopsis and soybean [16]. Temperate plant species have a survival ability in cooling and freezing temperatures due to the process of acclimatization to cold, while tropical climate species have little and no acclimatization capability at lower temperatures.

In plant species that have already described a mechanism of protection against cold periods, protection was explained by the passage through a period of freezing cold, where plants can develop adaptations at physiological, cellular, biochemical and molecular levels, their survival in periods of freezing cold [17]. Studies indicate that acclimatization has a genetic basis $[14,18]$. One of the genes responsible for this discovery was the one encoding the ICE1 protein, which is a transcription factor that binds to promoter regions associated with other transcription factors, one in particular CBF3 [19], which in turn activate transcription of protein genes in response to cold, COR proteins [20]. These activated genes stimulate the production of low molecular weight cryoprotective metabolites such as raffinose, sucrose and proline, and the production of polypeptides that in different ways protect plants from damage caused by stress $[21,22]$.

Our results suggest the existence of these same mechanisms, or similar, also in yerba mate. As mentioned above, this plant naturally occurs in subtropical lands, but also in temperate regions. In the south of Brazil (where we can find yerba mate) chilling temperatures are common in winter, what makes particularly interesting to know the possibility of the presence of cold responses in the yerba mate. Additional studies may define the physiological characteristics and limits of this defense mechanism against cold stress, its genetic basis, variability and heritability. Knowing this phenomenon better, it will be possible to incorporate the concept of acclimatization into research on breeding programs. 


\section{References}

1. Rodolfo B. Sobre a Erva-mate. 2018: Ref.: https://goo.gl/1vQQvK

2. Mazur L, Peralta-Zamora G, Demczuk BJ, Ribani RH. Application of multivariate calibration and NIR spectroscopy for the quantification of methylxantines in yerba mate (llex paraguariensis). Journal of Food Composition and Analysis. 2014; 35: 55-60. Ref.: https://goo.gl/b127nn

3. Simeão RM, Sturion JA, Resende MDV, Fernandes JSC, Neiverth DD, et al. Avaliação genética em erva-mate pelo procedimento BLUP individual multivariado sob interação genótipo $\mathrm{x}$ ambiente. Pesquisa Agropecuária Brasileira, Brasíli. 2002; 3:.1589-1596. Ref.: https://goo.gl/u8G2Tz

4. Bracesco N, Sanchez AG, Contreras V, Menini T, Gugliucci A. Recent advances on llex paraguariensis research: minireview. J Ethnopharmacol. 2011; 136: 378-384. Ref.: https://goo.gl/Ckvwqp

5. Resende MDV, Sturion JA, Mendes S. Genética e melhoramento da erva-mate (Ilex paraguariensis St Hil.). Colombo: EMBRAPA-CNPF. 1995; 33: Ref.: https://goo.gl/4AWnFG

6. Hasegawa PM, Bressan RA, Zhu JK, Bohnert HJ. Plant cellular and molecular responses to high salinity. Annu Rev Plant Physiol Plant Mol Bio. 2000; 51: 463-499. Ref.: https://goo.gl/VZf4x7

7. Zhu JK. Salt and drought stress signal transduction in plants. Annu Rev Plant Biol. 2002; 53: 247-273. Ref.: https://goo.gl/BsX2UB

8. Taiz L, Zeiger E. Plant Physiology. 3 ed. Ed Artmed, Porto Alegre. 2002. Ref.: https://goo.gl/1GTKoc

9. Palva ET, Heino P. Molecular mechanism of plant cold acclimation and freezing tolerance. Plant Cold Hardiness. Springer, Boston, MA. 1997; 3-14. Ref.: https://goo.gl/xTSFcR

10. Xin Z, Browse J. Cold comfort farm: the acclimation of plants to freezing temperatures. Plant, Cell \& Environment. 23.9 2000; 893-902. Ref.: https://goo.gl/FyxFCh

11. Thohamashow, M. F. Plant cold acclimation, freezing tolerance genes and regulatory mecnisms. Annu Rev Plant Physiol Plant Mol Biol. 1999; 50: 571-599. Ref.: https://goo.gl/ThbcBD

12. Orvar BL, Sangwan V, Omann F, Dhindsa RS. Early steps in cold sensing by plant cells: The role of actin cytoskeleton and membrane fluidity. Plant J. 2000; 23: 785-794,. Ref.: https://goo.gl/mwvzTK

13. Knight $\mathrm{H}$. Calcium signaling during abiotic stress in plants. Int Rev Cytol. 2000; 195: 269-325. Ref.: https://goo.gl/Ni94J2

14. Jaglo-Ottosen KR, Gilmour SJ, Zarka DG, Schabenberger O, Thomashow MF. Arabidopsis CBF1 overexpression induces COR genes and enhances freezing tolerance. Scienci. 1998; 280: 104-106. Ref.: https://goo.gl/x418ep

15. Rocha FR, Papini-Terzi FS, Nishiyama MY, Jr., Vêncio RZN, Vicentini R, et al. Signal transductionrelated responses to phytohormones and environmental challenges in sugarcane. BMC Genomics. 2007; 8: 1-22. Ref.: https://goo.gl/5GppB5

16. Asnaghi C, Paulet F, Kaye C, Grivet L, Horau JY, et al. Target mapping of a sugarcane rust resistance gene (bru1) using bulked segregant analysis and AFLP markers. Theos Appl Genet. 2004; 108: 759764. Ref.: https://goo.gl/dpcU7u

17. Janská $A$, Marsík $P$, Zelenková $S$, Ovesná J. Cold stress and acclimation-what is important for metabolic adjustment? Plant Biol. (Stuttg.). 2010; 12: 395-405. Ref.: https://goo.gl/7ErQow

18. Monroy AF, Sarhan F, Dhindsa R. Cold-Induced Changes in Freezing Tolerance, Protein Phosphorylation, and Gene Expression (Evidence for a Role of Calcium). Plant Physiol.1993; 102: 1227-1235. Ref.: https://goo.gl/n7S6ES

19. Shinwari ZK, Nakashima K, Miura S, Kasuga M, Seki M, et al. An Arabidopsis gene family encoding DRE/CRT binding proteins involved in low-temperature-responsive gene expression. Biochem Biophys Res Commun. 1998; 250: 161-170. Ref.: https://goo.gl/ugPuEW

20. Artus NN, Uemura M, Steponkus PL, Gilmour SJ, Lin C, et al. Constitutive expression of the cold regulated Arabdopsis thaliana COR15a gene affects both chloroplast and protoplast freezing tolerance. Proc Natl Acad Sci U S A. 1996; 93: 13404-13409. Ref.: https://goo.gl/x7yHgG

21. Cook D, Fowler S, Fiehn O, Thomashow MF. A prominent role for the CBF cold responsive pathway in configuring the low-temperature metabolome of Arabidopsis. Proc Natl Acad Sci. 2004; 101: 1524315248. Ref.: https://goo.gl/DoR6C6

22. Steponkus PL, Uemura MS, Joseph RA, Gilmour SJ, Thomashow MF. Mode os action of the COR15a gene on the freezing tolerance of Arabidopsis thaliana. Proc Natl Acad Sci U S A. 1998; 95: 14570 14575. Ref.: https://goo.gl/JyVQkQ 